\title{
Ostrich - A diversification option for east coast farms?
}

\author{
C.D.A. BROWN ${ }^{1}$ and K.F. THOMPSON ${ }^{2}$ \\ ${ }^{1}$ Agriculture New Zealand, Private Bag 50034, Mosgiel \\ ${ }^{2}$ Animal and Veterinary Sciences Group, Box 84, Lincoln University
}

\begin{abstract}
Ostrich are currently being promoted as an alternative to sheep, cattle and deer. Although current bird prices are not sustainable, New Zealand and overseas experience to date suggest ostrich can be farmed successfully and profitability long term. Climate and terrain of the east coast of New Zealand suit ostrich physical requirements. It has been suggested that production systems will develop in which grazed herbage will provide $60 \%$ or more of the nutritional requirements. The ability to graze low-cost herbage combined with a reproduction rate of about 25 progeny per hen per year indicate that ostrich production systems may be three times more efficient than beef or deer at turning feed into lean meat. The low fat and low cholesterol meat is likely to be the primary product and is already being sold in international markets. There is also a market for the leather, feathers and oil by-products.
\end{abstract}

Keywords: diversification, east coast, farming systems, meat, ostrich

\section{Introduction}

Ostrich are being promoted as an alternative to traditional pastoral farming of sheep, cattle and deer. Current interest in ostrich has been encouraged by investment "hype" and the suggestion that there may be large returns on invested capital. However, the long-term success of ostrich farming will depend on sustained demand for their products and the integration of these grazing birds into intensive pastoral farming systems.

Ostrich have been farmed in South Africa since 1838. Initially, feathers were the main commercial product. In the early 1900 s ostrich were introduced into other countries, including Australia and New Zealand. A change in clothing fashion coinciding with World War I led to a collapse in ostrich farming. The revival of ostrich farming began in South Africa after World War II, initially driven demand for feathers, but more lately by the demand for leather. By 1993, South African ostrich farmers were receiving the equivalent of about NZ\$800 per slaughter bird. The contribution to this value was $75 \%$ from hides, $7 \%$ from feathers, and $18 \%$ from meat (Smith et al. 1995). In the last 15 years ostrich farming has been established in other Southern African countries, Europe, North America and Australia. The modern renewal of interest in commercial farming of ostrich in New Zealand began in 1993. In June 1995 there were 650 birds; in May 1996 there were an estimated 3600 birds, of which 450 were hatched from eggs laid in New Zealand (M. Taylor, NZ Ostrich Assoc. pers. comm.). Importation of eggs and live birds were the primary source of the increased numbers in 1995-96.

This paper outlines the management requirements for successful ostrich production, and considers likely technical issues associated with ostrich farming in the dry east coast environment.

\section{Growth and reproduction}

With good feeding, the mature size of $90-130 \mathrm{~kg}$ can be reached at 12-14 months of age (Degen et al. 1991). There is variation in both growth rate and time to reach mature size in ostrich from different sources (du Preez et al. 1992). Smith et al. (1995) reported achieving $35-38 \mathrm{~kg}$ usable meat from 6 to 7 -month birds with a feed conversion ratio of $4: 1$. Sexual maturity occurs at 2-2.5 years for females and about 6 months later for males. Breeding activity is common in birds over 25 years of age (Smith et al. 1995).

Hens lay an egg of 1.2-1.7 kg mass every second day, producing about 50 eggs during a breeding season under farmed conditions. Chicks hatch after 42 days of incubation.

There is considerable variation among birds in the number of eggs laid, the fertility level and the eventual hatch rate of chicks. Management, particularly hygiene associated with egg collection and incubation, contributes to this variability. Chick mortality can be high, and Smith et al. (1995) quotes average mortality rates from South Africa of $50 \%, 10 \%$ and $3 \%$ for chicks up to 3 months, 3-6 months and 6-14 months, respectively. To date, experienced farmers in New Zealand and Australia have achieved lower mortality rates than those reported from South Africa and good 
operators expect to hatch over $80 \%$ of eggs laid and lose less than $10 \%$ of the chicks. The industry in New Zealand quotes an average annual figure of 25 chicks surviving to 3 months per breeding hen.

Incredibly, a breed society was not established in South Africa until 1994. Consequently. There are limited data on genetic parameters for ostrich production traits. Smith et al. (1995) expects the heritability for liveweight gain to be relatively high, as it is for most farmed production species, but reproductive heritabilities to be lower.

\section{Products}

Meat is likely to be the primary product from New Zealand farmed ostrich. Trial slaughterings by the Australian Ostrich Corporation have averaged $35 \mathrm{~kg}$ of lean meat from 12-month-old birds averaging $100 \mathrm{~kg}$ liveweight (Chas Dale, GM, pers. comm.). Ostrich produce red meat with a subtle game taste. The meat is low in fat and cholesterol (Table 1). It has appeal to the affluent health-conscious European and Asian markets. The Australian Ostrich Corporation has received unsolicited enquires to supply meat to 19 countries. Canadians who are processing ostrich for the local restaurant market have received enquires for meat from Japan, South Korea and China, and as yet are unable to supply.

Body skin leather is made into jackets and briefcases that retail for the equivalent of NZ\$3000 to NZ\$5000. The price is influenced by the current world shortage of ostrich leather. However, the distinctive quill pattern that gives the body leather its unique appearance may restrict its use. Leather from the legs has an appearance similar to crocodile leather and is used in similar products. Over 40 tanneries throughout the world have the expertise to process ostrich skins to leather.
Leather characteristics change as a bird ages. The pelt increases in strength and follicle shape changes as feathers become "ripe". For this latter reason, birds are not normally slaughtered in South Africa until 14 months of age, despite reaching adequate body size to produce the $1.20 \mathrm{dm}^{2}$ size skin by 10 months (Mellett 1995).

Feather production is a specialised industry, and welfare considerations are likely to preclude feather plucking in New Zealand. Sales literature quotes byproducts such as eyes for cornea transplants and oil for cosmetic purposes as adding to the value of slaughter birds.

The industry in New Zealand is currently in the breeding-up stage and bird price is determined by the "investor market". An indication of present commercial returns can be gained from other countries. Farmers in the USA and Canada have been receiving NZ\$1200 to $\$ 1500$ per bird at $10-12$ months of age. In 1995 South African farmers were receiving approximately NZ\$800 for 12-14-month-old birds, and the Australian Ostrich Corporation guarantees approximately NZ\$900 for birds of about $100 \mathrm{~kg}$ liveweight. We expect these prices will drop as bird numbers increase.

\section{Productivity and profitability}

The reproductive performance of ostrich has a major impact on meat output. Not all eggs hatch and chick mortality under 3 months can be high. The industry uses an average figure of 20 live chicks per hen per year and we believe this is a reasonable average figure. The variability among birds is high and some people who have purchased one or two hens and find they are of below-average performance are likely to be disappointed.

Estimates of energy requirements for ostrich are not as well established as they are for sheep, cattle and deer.

Table 1 Comparative nutrient values of a range of meats.

\begin{tabular}{lccccccccc}
\hline & $\begin{array}{c}\text { Weight } \\
\mathrm{g}\end{array}$ & Calories & $\begin{array}{c}\text { Protein } \\
\mathrm{g}\end{array}$ & $\begin{array}{c}\text { Fat. } \\
\mathrm{g}\end{array}$ & $\begin{array}{c}\text { Sat } \\
\mathrm{g}\end{array}$ & $\begin{array}{c}\text { Mono. unsat } \\
\mathrm{g}\end{array}$ & $\begin{array}{c}\text { Poly. unsat } \\
\mathrm{g}\end{array}$ & $\begin{array}{c}\text { Cholesterol } \\
\mathrm{mg}\end{array}$ & $\begin{array}{c}\text { Carbo. Calcium } \\
\mathrm{g}\end{array}$ \\
$\mathrm{mg}$
\end{tabular}

From “Nutritive Value of Foods" USDA, Home \& Garden Bulletin No. 72 and AVS Quality Testing Laboratory Report No. C80-0100 for Dr Kevin Owen 27/1/89. 
From calorimetric studies Swart et al. (1993) determined the maintenance requirements for adult ostrich to be:

$$
\begin{aligned}
& \mathrm{MR}=0.44 * \mathrm{LW}^{0.75} \\
& (\mathrm{MJ} \mathrm{ME} / \text { day })
\end{aligned}
$$

Thompson (1996) used this as a basis for estimating the requirements for breeding ostrich in an outdoor New Zealand environment and suggested that the annual requirement was $780 \mathrm{~kg}$ DM for the hen and $640 \mathrm{~kg} \mathrm{DM}$ for the cock. Such estimates are compatible with the average daily consumption of all mash rations presented in Table 2. Degen et al. (1991) derived a relationship to produce metabolised energy intake for growing birds. We have estimated the annual dry matter requirement for a breeding pair (hen plus cock) producing 25 progeny raised to $115 \mathrm{~kg}$ liveweight in 13 months, thus producing $1000 \mathrm{~kg}$ of lean meat. This ostrich system requires $17 \mathrm{~kg}$ DM per $\mathrm{kg}$ meat and this is compared with estimates for existing pastoral systems (Table 3). The available feed intake production data suggest that ostrich may be up to three times more efficient than deer or beef cattle and four times more efficient than sheep at producing meat per $\mathrm{kg}$ DM.

However, ostrich systems do not fit the annual pattern of pasture production as well as sheep. In addition, it is not known the extent to which commercial feed, balanced for essential amino acids and minerals, can be replaced by a pasture diet. The current feeding practice on many New Zealand farms is for commercial feed to provide $40 \%$ or less of requirements and still achieve satisfactory growth and reproduction per-
Table 2 Average daily consumption by ostriches of different

\begin{tabular}{|c|c|c|c|c|}
\hline & & $\begin{array}{c}\text { Age } \\
\text { (in months) }\end{array}$ & $\begin{array}{l}\text { Liveweight } \\
\text { range } \\
(\mathrm{kg})\end{array}$ & $\begin{array}{c}\text { Average } \\
\text { daily intake } \\
\text { (kg DM) }\end{array}$ \\
\hline Chick & & $\begin{array}{c}0-1 \\
1-2.5\end{array}$ & $\begin{array}{c}0.73-3 \\
3-15\end{array}$ & $\begin{array}{l}0.12 \\
0.36\end{array}$ \\
\hline Juvenile & & $\begin{array}{c}2.5-6 \\
6-11 \\
11-14\end{array}$ & $\begin{array}{c}15-60 \\
60-80 \\
80-100\end{array}$ & $\begin{array}{l}1.5 \\
2.5 \\
2.2\end{array}$ \\
\hline Breeder & $\begin{array}{l}\text { - maintenance } \\
\text { - breeding season }\end{array}$ & $\begin{array}{l}\text { over } 14 \\
\text { over } 30\end{array}$ & $\begin{array}{l}100-120 \\
110-120\end{array}$ & $\begin{array}{l}2.3 \\
2.5\end{array}$ \\
\hline
\end{tabular}
age groups on all mash rations.

Source: Kreibich \& Sommer 1995.

formance. Table 4 outlines the present gross return per $\mathrm{kg}$ of DM consumed. These calculations assume a sale price of NZ\$500 for 13-month birds. This is below the current prices for slaughter birds in Australia, South Africa or USA. The high reproductive efficiency of ostrich gives a gross return per $\mathrm{kg}$ of DM consumed of $\$ 0.50$, compared with 6 to $17 \phi$ for conventional systems. Note that 20 to $40 \%$ of the total feed consumption will comprise pelleted ration rather than herbage. The cost per $\mathrm{kg}$ of DM of hard feed relative to the gross margin per $\mathrm{kg}$ consumed will effect the return achieved per $\mathrm{kg}$ of herbage DM.

However, this return is highly sensitive to reproductive efficiency and bird price (Table 4). With bird numbers increasing world wide, the resulting increased supply of meat will almost certainly result in reduced prices for slaughter birds. At reduced bird prices, farmers will need to reduce feed costs to maintain profit margins, primarily through greater use of grazed herbage.

\begin{tabular}{|c|c|c|c|c|c|c|c|c|}
\hline Description & \multicolumn{2}{|c|}{$\begin{array}{l}\text { kg DM consumed, } \\
\text { adult stock }\end{array}$} & $\begin{array}{l}\text { kg DM consumed, } \\
\text { growing stock }\end{array}$ & $\begin{array}{l}\text { Total kg DM } \\
\text { consumed }\end{array}$ & $\begin{array}{l}\mathrm{kg} \text { lean meat } \\
\text { produced }\end{array}$ & \multicolumn{2}{|c|}{$\begin{array}{l}\mathrm{kg} \text { DM per kg } \\
\text { lean meat }\end{array}$} & $\begin{array}{c}\text { Gross margin } \\
\text { per kg DM }\end{array}$ \\
\hline neep & \multicolumn{2}{|c|}{565} & 270 & 835 & 13.5 & & & $8 c$ \\
\hline eef & \multicolumn{2}{|c|}{3840} & 2200 & 60 & 110 & & & $5 c$ \\
\hline eer & \multicolumn{2}{|c|}{745} & 655 & 1400 & 31 & & 6 & $17 c$ \\
\hline trich & \multicolumn{2}{|c|}{1420} & 15880 & 17300 & 1000 & & 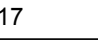 & $50 c$ \\
\hline Assumptions: & \multicolumn{8}{|c|}{$\begin{array}{l}\text { - } \quad 10.8 \text { megajoules of metabolisable energy per kg dry matter } \\
\text { - } \quad \text { Animal growth rates and feed demand based on good industry averages, modelled through computer program } \\
\text { - } \quad \text { Stockpol". } \\
\text { - } \quad \text { Retrich production reflects likely future industry averages for pasture based system. }\end{array}$} \\
\hline \multicolumn{2}{|c|}{$\begin{array}{l}\text { Sheep } \\
58 \mathrm{~kg} \text { ewe } \\
135 \% \text { lambing } \\
17 \mathrm{~kg} \text { works lamb: } \$ 44 \\
\text { crossbred wool } \$ 3 / \mathrm{kg} \text { (greasy) }\end{array}$} & \multicolumn{2}{|c|}{$\begin{array}{l}\text { Beef } \\
500 \mathrm{~kg} \text { cow } \\
92 \% \text { calving } \\
\text { calve as } 2 \text {-yr-old } \\
\text { 20-month heifers: } 200 \mathrm{~kg}: \$ 325 \\
20 \text {-month steers: } 250 \mathrm{~kg} \text { cow: } \$ 450\end{array}$} & $\begin{array}{ll} & \text { Deer } \\
& 103 \mathrm{~kg} \mathrm{~h} \\
& 89 \% \text { we } \\
& \text { venison } \\
& 18-\text { mont } \\
450 & 18-\text {-mont } \\
& \text { velvet }\end{array}$ & $\begin{array}{l}18 \text { months } \\
\text { inds: } 51 \mathrm{~kg} \text { cow } \\
\text { tags: } 62 \mathrm{~kg} \text { cow }\end{array}$ & 330 & $\begin{array}{l}\text { Ostrich } \\
120 \mathrm{~kg} \mathrm{~b} \\
25 \mathrm{chick} \\
115 \mathrm{~kg} \\
40 \mathrm{~kg} \mathrm{~m} \\
\$ 500 \mathrm{pe}\end{array}$ & $\begin{array}{l}\text { reeding pair } \\
\text { grown to } \\
13 \text { months } \\
\text { at per bird } \\
13 \text {-month bird }\end{array}$ \\
\hline
\end{tabular}

Table 3 Comparison of typical feed required and lean meat production for various stock systems. 
Table 4 Sensitivity table, gross returns from ostrich $\$$ per $\mathrm{kg}$ DM dry matter consumed.

\begin{tabular}{lccccc}
\hline $\begin{array}{l}\text { Bird price } \\
\text { chicks sold per } \\
\text { breeding pair }\end{array}$ & $\$ 300$ & $\$ 400$ & $\$ 500$ & $\$ 600$ & $\$ 700$ \\
\hline 5 & $(0.14)$ & $(0.03)$ & 0.07 & 0.17 & 0.27 \\
10 & 0.05 & 0.18 & 0.30 & 0.43 & 0.55 \\
15 & 0.14 & 0.27 & 0.41 & 0.54 & 0.68 \\
20 & 0.18 & 0.32 & 0.47 & 0.61 & 0.75 \\
25 & 0.21 & 0.36 & 0.50 & 0.65 & 0.79 \\
30 & 0.24 & 0.38 & 0.53 & 0.68 & 0.82 \\
35 & 0.25 & 0.40 & 0.55 & 0.70 & 0.85 \\
\hline
\end{tabular}

Assumptions:Birds sold at 13 months at $115 \mathrm{~kg}$ liveweight.

\section{Suitability of pastures for pasture grazing}

Ostrich are more suited to a grazing regime than production poultry. Their digestive system is more similar to that of a pig or horse than a chicken, in that ostrich have a functional large intestine where microbial digestion occurs. Smith et al. (1995) cited experiments that showed that fibre fermentation in the colon could contribute as much as $76 \%$ of the maintenance requirement for growing birds. They also showed that ostrich, compared with fowl, were considerably more efficient at digesting fibre and protein. The practice of using pig or poultry standards for ostrich is likely to lead to inappropriate rations and level of feeding. Lucerne has been successfully used in conjunction with commercial feed in South Africa, Australia and Texas.

Ostrich are territorial, and less suited to rotational grazing than sheep, cattle or deer. Mating birds should be left in their paddock for most of the year. Spring and summer pasture production surplus to the ostrich requirement is being controlled either by regular or concurrent grazing by sheep. Mobs of juveniles may be moved around paddocks with which they are familiar, and electric fencing has been used successfully in New Zealand for break-feeding of lucerne to juvenile birds.

Although ostrich can handle fibre, the primary digestive process is in the proventriculus where acid and enzyme digestion occurs. Therefore pasture species are likely to influence animal performance. Little is known about plant species and comparative bird performance, but it is assumed that species that are of higher nutritive value than ryegrass for ruminants are likely to also be of higher nutritive value for ostrich.

\section{Disease}

Ostrich are host to internal parasites. The most potentially pathogenic is Libyostrongylus douglassi (proventricular wire worm). Ivermectin is being used successfully in Australia for parasite control (Black
1995). Libyostrongylus is not yet present in New Zealand. It is likely to arrive, and be a major problem where ostrich are managed in an intensive grazing system. Roundworms and tapeworms that infect sheep and cattle have not been observed in ostrich.

Ostrich have evolved in a dry environment with low relative humidity. They have similar moisture conservation characteristics as camels, and conserve moisture before exhaling air. Their air-way systems are susceptible to the fungal infection aspergillosis, which can be fatal if not treated. This condition is more likely in humid regions, so the drier areas of the east coast should be suitable for ostrich.

\section{Environmental considerations}

Adults are relatively hardy and are commercially farmed in environments as diverse as the semi-desert of South Africa, Israel, or Texas to the frozen winters with $-40^{\circ}$ temperatures in Canada. The pelage gives effective insulation against dry cold, but as ostrich lack down feathers, and the feathers have no oil, they cope less well in rain, particularly if associated with wind. Ostrich do not produce methane. Some farmers consider that breeding birds require visual privacy for best reproductive performance.

\section{Summary}

Ostrich have a high reproductive rate, and under commercial farming conditions in New Zealand are expected on average to produce in excess of 20 live chicks per breeding hen per year. Combined with high growth capacity which leads to a $100 \mathrm{~kg}$ bird at 12 months of age, this means ostrich meat production systems could possibly be three times more efficient than cattle or deer. The meat and leather are highly valued products and the red meat product is likely to attract demand in affluent Asian markets.

Pastures of high nutritive value will be required and new grazing management techniques and new pasture mixes are likely to be required.

Ostrich, particularly adults, are very territorial, which makes set-stocking the most appropriate management system. Management systems to control excessive summer pasture growth will need to be developed. Shelter from wind, and visual shelter, are also likely requirements in the east coast environment.

Overall we believe that ostrich have considerable potential as an alternative to sheep, cattle and deer. Even at meat prices comparable with those of other red meats, their ability to graze herbage, and high reproductive rate, suggest that satisfactory profit margins on feed inputs can be obtained. 


\section{REFERENCES}

Black, D.G. 1995. Ostrich examination. post graduate committee in veterinary science, University of Sydney. p. 15.

Degen, A.A.; Kam, M.; Roenstrauch, A.; Plavnik, I. 1991. Growth rate, total body water volume, drymatter intake and water consumption of domesticated ostrich (Struthio camelus). British Society of Animal Production 52: 225-232.

Kreibich, A.; Sommer, M. 1995. In: Ostrich farm management. Ed. Kreibich and Sommer p.53.

Mellett, F.D. 1995. Ostrich products. pp. 28-44. In: Practical guide for ostrich management and ostrich products. Ed. W.A. Smith. du Preez, J.J.; Jarvis, M.J.F.; Capatos, D.; de Kock, J. 1992. A note on growth curves for the ostrich (Struthio camelus). British Society of Animal Production 54: 150-152.

Smith, W.A.; Cilliers, S.C.; Mellet, F.D.; van Schalkwyk, S.J. 1995. Ostrich production - a South African perspective. In: Biotechnology in the feed industry. Proceedings of Alltech's eleventh annual symposium. Ed. T.P. Lyons and K.A Jacques.

Swart, D.; Siebrits, F.K.; Hayes, J.P. 1993. South African journal of animal science.

Thompson, K.F. 1996. Ostrich energy requirements and digestion. New Zealand ostrich journal 1 (Autumn): 14. 
